That certain diseases may arise from the "bites" of insects has been surmised long before the microbial origin of disease was known, many theories were naturally based on insufficient evidence because the key to the riddle had not then been found. In some of the earliest records of epidemics any concurrent phenomena was thought to be the cause, thus the plague at Nimeguen, in Holland, in the seventeenth century, was said to be announced by swarms of insects and meteors.

All observations are of use, although in the light of present knowledge they may not bear the same interpretation as was originally put upon them ; as a suggestion for investigation by experimental methods they may serve a purpose.

Dr. George H. F. Nuttall in this monograph has been at great pains to collect observations on the point from all sources, and has supplemented these with some experimental researches of his own.

Insects-- using the term in its popular sense-may play a passive rôle in the propagation of disease. It is obvious that flies, for instance, after soiling their bodies in contaminated matter, may afterwards infect articles of food, especially milk ; and no doubt many cases of typhoid fever are caused in this way. In India, where typhoid fever attacks so many of our troops, the refuse matter is placed outside the camp, and it has been suggested that articles of food in the camp might become infected by dust carried by the wind when it blows from the direction of the refuse matter; but it is more than likely that flies carried by the wind play a more important part, for they would seek out the food. The same may be said of cholera ; in fact, an instance is given where milk was left out in the open in a jail in India at the time of a cholera epidemic, and it became infected with the cholera microbe by means of flies, whereas milk left out in another yard where there were no cholera cases and which was separated from the other yard by a high wall did not become infected.

In playing an active rôle insects may conceivably cause infection by "biting" after having "bitten" an individual suffering from an infectious disease or after feeding on contaminated substances, for instance, the body of an animal dead of anthrax. Experiments in this direction do not seem to have been very successful in the cases of bugs and fleas, which were the insects experimented with; but it was shown that anthrax and plague microbes do not survive more than a few days at most in the bodies of the insects. Even if the "bite" of an infected insect is harmless, it might be otherwise if the insect were crushed on the spot bitten, and the place scratched; such a procedure might be fraught with danger supposing the insect had recently been feeding on infected matter.

With respect to the tsetse-fly disease in domesticated animals, there is conclusive experimental proof that the fly carries the micro-organism or hæmatosine in this case from diseased to healthy animals.

The filariae, according to Manson, go through changes in the stomach of the mosquito, and finally make their way out into water in which the insects have died, and man becomes infected by drinking the water. In this case and in malaria the insect seems to act as an intermediary host to man. The mosquito- of which one species, the anopheles, seems to be mostly concernedtakes up the organism in the blood of the malarious subject, and, according to Manson, infects soil or water by dying in it ; Ross and others, however, say it inferts healthy persons by biting them after biting a malarious patient.

It is interesting to note that most of our previous notions as to the localities and time of year that malaria occurs, and the precautions adopted to prevent being attacked still hold good, mutatis mutandis, for the mosquito theory.

$$
\text { C. B. S. }
$$

\section{ETHNOGRAPHICAL MUSEUMS}

I N NATURE of September I4, attention was called to the rapid progress of ethnographical museums in Germany, and to the unsatisfactory state of ethnography in our own country. Since that time two things have happened which confirm the view then taken of the position of our national collections.

In the first place, one of the distinguished keepers of the Museum für Völkerkunde in Berlin has recently visited London, and has stated that the enlargement of the museum or its supercession by a completely new building will be seriously considered in the near future. When it is remembered that the Museum für Völkerkunde is already so enormously superior to anything which we have in this country, that it stands absolutely in a class by itself, it can easily be guessed that the projected improvements threaten to leave us in a position of inferiority positively humiliating. For even as matters now stand, the German collections are nearly ten times as good as our own.

The second occurrence to which we have alluded, is the issue of a report upon European anthropological museums by Mr. George A. Dorsey, of the Field Columbian Museum, who made a tour of the principal European cities in the autumn of last year. Extracts from his report have been published in the form of a short paper in the American Anthropologist for July, 1899, and it is therefore accessible to every one who feels any interest in the subject.

Mr. Dorsey begins by complaining that the collections illustrating the various branches of anthropology in Europe are all scattered about in different buildings. In London, if you wish to study man as an animal, you must go to the British Museum of Natural History in Cromwell Road, or to the Royal College of Surgeons ; if you wish to study primitive art and industry, you must go to Bloomsbury. In Paris you must wander from the Jardin des Plantes to the Trocadéro, and so on in other cities. The great fields of anthropology are nowhere adequately represented in a single building, and the advantages of concentration are lost.

After this preliminary condemnation, Mr. Dorsey proceeds to discuss several museums in detail. He has a well-merited word of praise for the Pitt-Rivers collection in the University Museum at Oxford, where the development of different branches of human industry may be studied in a manner impossible anywhere else. Coming to Berlin, he thinks that the Museum für Völkerkunde contains the largest amount of ethnographical material to be found in any one museum in the world; and he is inclined to believe that it possesses a greater number of specimens than any other two museums combined. The one drawback is that, large as the building is, it has long proved inadequate to the enormous expansion of the collections, and is in consequence terribly overcrowded. As we have already seen, this is an inconvenience which will in all probability soon be remedied.

Of the ethnographical collections in London, our American critic has naturally something to say. After noticing that, from the ethnographical point of view, London, like Paris, is disappointing, he continues: "The large hall [gallery] devoted to this subject in the British Museum is not well adapted to the purpose for which it is used; it is rather inaccessible, poorly lighted, and does not admit of a ready scientific classification of the objects therein deposited. Naturally, this hall contains many of the rarest and most valuable objects that have ever been obtained by any museum in the world; but owing to the causes already mentioned, and to the crowding of the cases, it is practically impossible for the visitor in a short time to form any idea of the value of the collection. There are many rare and unique specimens, but the collection as a whole cannot be regarded as well illustrating 
the various fields of ethnography. . . . It is to be regretted that the capital of a nation which embraces in its domain so many and such diverse peoples should not possess a museum which shows the ethnic characteristics of some of these peoples in an adequate manner."

Mr. Dorsey has returned to his own country convinced that in the matter of the housing and exhibition of anthropological collections the United States have nothing to fear from comparison with Europe. He thinks that there is no building in Europe so admirably planned for museum purposes as the American Museum of Natural History at New York. Here ample space for future expansion has been allowed on a scale unequalled in Europe, and large, well-lighted and commodious quarters have been provided for storage and workrooms. He truly says that numerous workrooms with abundant light should be an essential feature of every museum. It is clear that in the United States the study of ethnology is being pursued with the same enthusiasm as in Germany, and that it has succeeded in a similar manner in securing a large measure of popular support. Viewed in the light of these facts, the conditions of things in Great Britain appears doubly deplorable.

\section{NOTES.}

THE complimentary dinner given to Major-General Sir John Donnelly on Tuesday, by his friends and former colleagues of the Department of Science and Art, is a testimony of the esteem in which he is held by all who have been associated with him in the work of the Department. Sir John Gorst presided, and in proposing the health of the guest of the evening, he pointed out that in 1859 , when Sir John Donnelly was entrusted with the control of the science branch of the Department, the total number of science students under instruction was 395, and the payments made on account of their instruction amounted to 2000\%. In 1897 , the number of students in Departmental classes was 197,796, and the grants amounted to 169,000 . These figures form the best of evidence as to the growth of the work of the Department under Sir John Donnelly's administration. In addition to Sir John Gorst and Sir John Donnelly, among other speakers at the dinner were:Captain Abney, Major-General Festing, Sir Norman Lockyer, Prof. Riicker, Sir George Gabriel Stokes, and Rear-Admiral Sir William Wharton.

Drs. Stevens ANd Christophers, of the Royal Society Malaria Commission, left Liverpool on December 9 for Sierra Leone, where they will continue their investigations on malaria. At Blantyre, in East Africa, where they were before, they gave more attention to investigating the relation of malaria to blackwater fever, which is very prevalent at that spot. Many persons deny the connection between the two, but it is a point that still requires to be settled. On the West Coast they will probably investigate the disease from the point of view of the mosquito theory.

Prof. Georges Lemoine has been elected a member of the section of chemistry of the Paris Academy of Sciences, in succession to the late Prof. Friedel.

THE following are among the lectures to be delivered at the Royal Institution before next Easter:-Mr. C. Vernon Boys, six Christmas lectures (specially adapted for young people) on fluids in motion and at rest, experimentally illustrated; Prof. E. Ray Lankester, twelve lectures on the structure and classification of fishes; Dr. W. H. Rivers, three lectures on the senses of primitive man; Prof. H. H. Turner, three lectures on modern astronomy; Dr. Charles Waldstein, three lectures on recent excavations at Argive Heræum (in Greece); Lord Rayleigh, six lectures on polarised light. The Friday evening meetings will begin on January 19, when a discourse will be NO. 1572 , VOL. $6 \mathrm{I}]$ given by Lord Rayleigh, on flight; succeeding discourses will probably be given by the Hon. C. A. Parsons, Prof. J. Reynolds Green, Mr. H. Warington Smyth, Prof. J. H. Poynting, Major Ronald Ross, Prof. Frank Clowes, Sir Benjamin Stone, M.P., Prof. J. Arthur Thomson, Sir A. Noble, Prof. Dewar, and other gentlemen.

AN agricultural conference for the West Indies will be held at Barbados on January 6 and 8, 1900. His Excellency, Sir James Hay, K.C.M.G., the Governor of Barbados, has promised to meet the representatives at Bridgetown on Saturday morning, January 6, and offer them a welcome to the island. Immediately after, the President (Dr. D. Morris, C.M.G.) will deliver the opening address, and the business of the conference will begin. A characteristic of the conference will be the presence of representatives of the leading agricultural societies in the West Indies. By this means it is anticipated that the conference will act as an educative agent of great value, and by enlisting the co-operation of those practically engaged in agriculture, its deliberations will have wider scope, and the influence of the conference will be more widely recognised. The list of subjects to be dealt with covers practically every branch of West Indian agriculture.

ORNITHOLOGY has suffered a severe loss by the death of Arthur Cowell Stark, M. B., who was killed by a Boer shell at Ladysmith on November I8. Dr. Stark was an ardent naturalist, and specially conversant with South African ornithology, having devoted many years to the study of the birds of the Cape Colony and adjoining countries. At the time of his death he had just completed for the Press the first volume of a work on South African birds, which is to form a portion of Mr. W. L. Sclater's "Fauna of South Africa." Dr. Stark was in England during the past summer engaged in the preparation of his book, but returned to the Cape in September last, and proceeded to Natal in order to continue his collections in that colony. When war broke out he offered his services as a volunteer on the Medical Staff, and was sent up to Ladysmith by the last train that passed the Boer army. Standing at the door of the Royal Hotel in Ladysmith, on November I8, he was struck by an exploded shell, and died shortly afterwards. Dr. Stark was a graduate of the University of Edinburgh, and a well-known member of the British Ornithologists' Union.

A Congres international des sciences ethnographiques will be held in connection with the Paris Exposition, on August 26September I, 1900. There will be seven sections, dealing respectively with general ethnology, sociology, and ethics; ethnographical psychology; religious sciences; linguistics and palæography ; sciences, arts, and industries; descriptive ethno. graphy. The treasurer of the organising committee is $M$. Leclère, rue Lecourbe, 54, Paris, and the general secretary, M. Greverath, rue d'Athènes 3 bis, to which address foreign correspondence should be sent.

THE essay on the scientific work of Lord Kelvin, contributed by Prof. G. F. Fitzgerald to an elegant volume just published by Messrs. James MacLehose and Sons, Gilasgow, is a masterpiece of appreciative writing. The volume contains a complete account of the celebrations on the occasion of Lord Kelvin's jubilee as professor of natural philosophy in the University of Glasgow ; it is thus of particular interest to the many friends who took part in the ceremonies, and to the scientific bodies who sent delegates and messages of congratulation. Preceding this report is Prof. Fitzgerald's essay, in which the nature and significance of Lord Kelvin's contributions to science are described with such remarkable lucidity that every one interested in the progress of natural knowledge would do well to read it. A striking photogravure of Lord Kelvin, from a portrait taken in 1898 , forms the frontispiece, and a portrait is given 